\title{
Anaerobic digestion of solid waste in RAS: Effect of reactor type on the biochemical acidogenic potential (BAP) and assessment of the biochemical methane potential (BMP) by a batch assay
}

Suhr, Karin Isabel; Letelier-Gordo, Carlos Octavio; Lund, Ivar

Published in:

Aquacultural Engineering

Link to article, DOI:

10.1016/j.aquaeng.2014.12.005

Publication date:

2015

Document Version

Peer reviewed version

Link back to DTU Orbit

Citation (APA):

Suhr, K. I., Letelier-Gordo, C. O., \& Lund, I. (2015). Anaerobic digestion of solid waste in RAS: Effect of reactor type on the biochemical acidogenic potential (BAP) and assessment of the biochemical methane potential (BMP) by a batch assay. Aquacultural Engineering, 443, 65-71. https://doi.org/10.1016/j.aquaeng.2014.12.005

\section{General rights}

Copyright and moral rights for the publications made accessible in the public portal are retained by the authors and/or other copyright owners and it is a condition of accessing publications that users recognise and abide by the legal requirements associated with these rights.

- Users may download and print one copy of any publication from the public portal for the purpose of private study or research.

- You may not further distribute the material or use it for any profit-making activity or commercial gain

- You may freely distribute the URL identifying the publication in the public portal 


\section{Accepted Manuscript}

Title: Anaerobic digestion of solid waste in RAS: Effect of reactor type on the biochemical acidogenic potential (BAP) and assessment of the biochemical methane potential (BMP) by a batch assay

Author: K.I. Suhr C.O. Letelier-Gordo I. Lund

PII: S0144-8609(14)00124-1

DOI:

Reference: http://dx.doi.org/doi:10.1016/j.aquaeng.2014.12.005

To appear in: AQUE 1790

Received date: Aquacultural Engineering

Revised date: $12-9-2014$

Accepted date:

Please cite this article as: Suhr, K.I., Letelier-Gordo, C.O., Lund, I.,Anaerobic digestion of solid waste in RAS: Effect of reactor type on the biochemical acidogenic potential (BAP) and assessment of the biochemical methane potential (BMP) by a batch assay, Aquacultural Engineering (2015), http://dx.doi.org/10.1016/j.aquaeng.2014.12.005

This is a PDF file of an unedited manuscript that has been accepted for publication. As a service to our customers we are providing this early version of the manuscript. The manuscript will undergo copyediting, typesetting, and review of the resulting proof before it is published in its final form. Please note that during the production process errors may be discovered which could affect the content, and all legal disclaimers that apply to the journal pertain. 
Anaerobic digestion of solid waste in RAS: Effect of reactor type on the biochemical acidogenic potential (BAP) and assessment of the biochemical methane potential (BMP) by a batch assay

Editorial reference: AQUE_AQUE-D-14-00092 To be published in: Aquacultural Engineering

List of Authors and their affiliations:

K.I. Suhr ${ }^{\mathrm{a}, *}$, C.O. Letelier-Gordo ${ }^{\mathrm{b}, 1}$, I. Lund ${ }^{\mathrm{a}}$.

${ }^{a}$ National Institute of Aquatic Resources, DTU Aqua, Section for Aquaculture, Technical University of Denmark, 9850 Hirtshals, Denmark. Tel: +45 3588 3273. Email: il@aqua.dtu.dk; ksu@aqua.dtu.dk.

${ }^{\mathrm{b}}$ DTU Environment, Department of Environmental Engineering, Bioenergy Group, Technical University of Denmark, Anker Engelunds Vej 1 - Building 101A, 2800 Kgs. Lyngby, Denmark.

${ }^{1}$ Present address: National Institute of Aquatic Resources, DTU Aqua, Section for Aquaculture, Technical University of Denmark, 9850 Hirtshals, Denmark. colg@aqua.dtu.dk.

*Corresponding author 


\begin{abstract}
Anaerobic digestion is a way to utilize the potential energy contained in solid waste produced in recirculating aquaculture systems (RASs), either by providing acidogenic products for driving heterotrophic denitrification on site or by directly producing combustive methane. In this study the biochemical acidogenic potential of solid waste from juvenile rainbow trout was evaluated by measuring the yield of volatile fatty acids (VFA) during anaerobic digestion by batch or fed-batch reactor operation at hydrolysis time (HT) / hydraulic retention time (HRT) of 1, 5, or 10 days (and for batch additional 14 and 20 days) in continuously stirred tank reactors. Generally, the VFA yield increased with time and no effect of the reactor type used was found within the time frame of the experiment. At 10 days HT or 10 days HRT the VFA yield reached $222.3 \pm 30.5$ and $203.4 \pm 11.2$ mg VFA g ${ }^{-1} \mathrm{TVS}_{0}$ (total volatile solids at day 0 ) in batch and fed-batch reactor, respectively. For the fed-batch reactor, increasing HRT from 5 to 10 days gained no significant additional VFA yield. Prolonging the batch reactor experiment to 20 days increased VFA production further $(273.9 \pm 1.6$ $\left.\mathrm{mg} \mathrm{VFA} \mathrm{g}^{-1} \mathrm{TVS}_{0}, \mathrm{n}=2\right)$. After 10 days HT / HRT, $16.8-23.5 \%$ of total Kjeldahl $\mathrm{N}$ was found as TAN and $44.3-53.0 \%$ of total $P$ was found as ortho-phosphate. A significant difference between reactor types was detected for the phosphorous dissolution at 5 days HT / HRT as a relatively steep increase (of a factor 2-3) in ortho-P content occurred in fed-batch reactors but similar steep increase was only notable after 10 days HT for batch reactors. No differences between reactor types at the other HT / HRT were recorded for P as well as (for all HT / HRT for) N. Based on this study a HRT of approximately 5 days would be recommended for the design of an acidogenic continuously stirred reactor tank in a RAS single-sludge denitrification set-up. The biochemical methane potential of the sludge was estimated to $318 \pm 29 \mathrm{~g} \mathrm{CH}_{4} \mathrm{~g}^{-1} \mathrm{TVS}_{0}$ by a batch assay and represented a higher utility of the solid waste when comparing the methane yield with the VFA yield (in COD units). This points towards a technological challenge of ultimately increase the acidogenic output to match the methane yield as both products are formed from the same reference point.
\end{abstract}

Keywords: Anaerobic digestion, biochemical acidogenic potential, reactor type, volatile fatty acid (VFA), biochemical methane potential, methane, sludge remineralization 


\section{Introduction ${ }^{1}$}

In countries with a strict environmental legislation the continuous success of land-based aquaculture will rely on the ability to treat and reduce the nutrient pollution load cost-efficiently. A distinct feature of recirculating aquaculture systems (RASs) compared to earthen ponds aquaculture and open net-pens is the considerable amount of solid fish waste /fecal matter collected in RASs. This makes sludge management an important part of RAS operation (Cripps and Bergheim, 2000, Sharrer et al., 2010) for mitigating potential pollution problems. Currently, a common way of treating the solid fish waste is by storage in sludge basins or Geotextile bags where the liquid part is drained off prior to spreading the sludge on agricultural land as fertilizer. An alternative use of the solid fish waste is utilization as a carbon source for denitrification (Aboutboul et al., 1995) or/ and in anaerobic digestion for methane generation (Lanari and Franci, 1998). From an environmental point of view controlled digesters are preferred to sludge basins because of the diffuse greenhouse gas emissions released from the basins (Mirzoyan et al. 2012).

In wastewater literature quantification of the fermentable fraction of the organic matter (corresponding to the maximum VFA concentration obtained at anaerobic conditions) is called the biochemical acidogenic potential (BAP) (Ruel et al. 2002; Lie and Welander, 1997). This fraction represents the majority of the easily biodegradable carbon compounds produced by anaerobic digestion. In a complete anaerobic digestion process, this fraction of biodegradable organic matter is further degraded to methane (Appels et al., 2008). Anaerobic digestion studies of solid fish waste

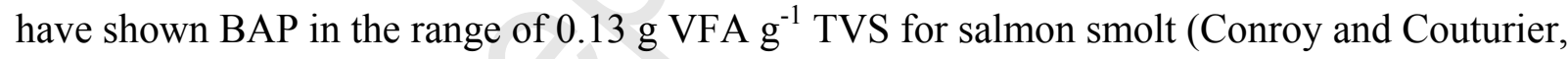
2010) and $0.15-0.21 \mathrm{~g} \mathrm{VFA} \mathrm{g}^{-1}$ TVS for rainbow trout (Suhr et al., 2013). When using the biodegradable organic matter present in the system as electron donors in heterotrophic denitrification the term "single-sludge denitrification" is used. This process has the advantage of reducing both the organic matter and nitrate discharge from RAS (van Rijn et al., 2006). In experimental zero-discharge RASs, single-sludge denitrification is integrated in the RAS and only the surplus solid waste not used for denitrification is ultimately subjected to biogas reactor digestion (Tal et al., 2009). Mirzoyan et al. (2010) reviewed the field of solid fish waste use in anaerobic

\footnotetext{
${ }^{1}$ Abbreviations: ANOVA: analysis of variance, B: Batch, BAP: Biochemical acidogenic potential, BMP: Biochemical methane potential, COD: chemical oxygen demand, FB: Fed-batch, HRT: Hydraulic retention time (Fed-batch experiment), HT: Hydrolysis time (Batch experiment), RAS: Recirculating aquaculture systems, SRT: Sludge retention time, SS: Suspended solids, STP: Standard temperature and pressure $\left(20^{\circ} \mathrm{C}, 1 \mathrm{~atm}.\right)$, TAN: Total ammonia nitrogen, TKN: Total Kjeldahl nitrogen, TP: Total phosphorus, TS: Total solids, TVS: Total volatile solids, VFA: Volatile fatty acid,
} 
biogas digesters and found organic matter (COD and VS) digestion efficiencies of up to nearly 100 $\%$. The methane output, however, varied considerably ( from 4 to $>80 \%$ methane of total gas produced) due to differences in operating conditions in the various studies (e.g. reactor types, feed type, loading rate, hydraulic retention time, $\mathrm{pH}$, salinity, temperature, composition, dilutions, etc.) (Mirzoyan et al., 2010).

The boost in denitrification rate by maximizing the dissolved and easily biodegradable part of the carbon source has been recognized for years (Bernard, 1974) and thus sludge pre-fermentors or side-stream hydrolysis operation is well established in conventional wastewater treatment plants (Pitman et al., 1992; Vollertsen et al., 2006). In the first part of the present study, we focused on acidogenic production in RAS sludge pre-fermentors for potential use in single-sludge denitrification. Such tanks should in general operate at SRT $<10 \mathrm{~d}$ to avoid competition and methane generation from the slow growing methanogens generally requiring a SRT of $10-28 \mathrm{~d}$ in anaerobic digesters (Metcalf and Eddy, 2003). In a second separate part of this study, the methane yield of the solid fish waste was assessed. The first step of anaerobic digestion (common for both acidogenic and methane production) is the hydrolysis of the suspended organic matter, which also commonly is the rate limiting step for the whole process (Eastman and Ferguson, 1981; van Lier et al., 2001). It has been shown that the electron acceptor conditions affect the development of the bacterial hydrolytic enzyme system (aerobic > anoxic > anaerobic) (Henze and Mladenovski, 1991) producing an apparent relationship between the specific growth rate and the specific enzyme production rate. The relative changes to this, however, are affected by the constituent microorganisms in the sludge and found to be more pronounced for pure culture systems than in activated sludge (Goel et al. 1997; Goel et al. 1998).

Anaerobic RAS sludge digestion studies are often performed in batch experiments (van Rijn et al., 1995, Conroy and Couturier, 2010) as this is most convenient. However, sludge hydrolysis and fermentation in a RAS facility will likely be operated in a kind of continuous or fed-batch mode due to the intermittent nature of the discharge from swirl separators and/or drum-filters. Theoretically, differences in environmental factors influence the microbial growth and thereby implicit their enzyme production. The objective of this study was to examine the effect of using a batch or fedbatch operational mode on BAP of RAS waste sludge in continuously stirred tank reactors. The simultaneous remineralization of $\mathrm{N}$ and $\mathrm{P}$ was also recorded in the study. Furthermore, in a separate trial the biochemical methane potential (BMP) of the same type of solid waste was assessed by a standardized (batch) assay for evaluating the yield at complete anaerobic digestion. 


\section{Material and Methods}

\subsection{The fish production unit supplying solid waste}

The RAS consisted of 12 fish tanks each with a volume of $600 \mathrm{~L}$ and holding approximately $27 \mathrm{~kg}$ juvenile rainbow trout (Oncorhynchus mykiss) (i.e. $327 \mathrm{~kg}$ in total). Fish were daily fed $3925 \mathrm{~g}$ (Biomar Enviro 920, $3 \mathrm{~mm}$ ) in total. The feeding was conducted during a 6 hours period per day,

and light was on 24 hours a day. Water temperature was $15{ }^{\circ} \mathrm{C}$ and freshwater intake was $275 \mathrm{~L} \mathrm{~h}^{-1}$

in the system with a total volume of approximately $17-18 \mathrm{~m}^{3}$. A $2 \mathrm{~L}$ container was mounted on the bottom of the outlet swirl-separator in each tank collecting the discharged solid waste and providing a means to observe if any feed waste occurred. The containers were discharged daily together with an additional refilling with RAS water. The discharged solid waste and additional flushing water from the 12 tanks were pooled together (44 L) before further distribution.

All experiments were performed during a period of 32 days.

\subsection{Anaerobic hydrolysis and fermentation in batch (B) reactors}

Subsamples from the pooled solid waste were incubated in 2 L Blue Cap bottles (in triplicate) at completely mixed conditions:mixing was achieved by magnetic stirrers. The bottles were closed (for maintaining anaerobic conditions) with 2-port screw caps; one port connected to a one-way valve allowing excess gas production to escape and the second port was used for sampling. Sampling (100 mL liquid bottle $\mathrm{m}^{-1}$ ) was performed at day; $0,1,2,5,10,14$, and 20, and will be referred to as hydrolysis time (HT). Nitrogen gas was used to purge the liquid hydrolysate mixture from the sampling tube immediately after sample retrieval. These batch reactors were kept at room temperature (in the same room as the fed-batch reactors below). However, due to more vigorous 
stirring and better isolated container walls, the batch reactors experienced slightly higher

temperature $\left(17.3 \pm 0.7{ }^{\circ} \mathrm{C}\right)$ than fed-batch reactors $\left(15.4 \pm 0.7^{\circ} \mathrm{C}\right)$

\subsection{Anaerobic hydrolysis and fermentation in fed-batch (FB) reactors}

The pooled solid waste was distributed while mechanically stirred (by a drilling machine with a whisk inserted) into $20 \mathrm{~L}$ reactors in quantities of $16 \mathrm{~L} \mathrm{~d}^{-1}, 4 \mathrm{~L} \mathrm{~d}^{-1}$ and of $2 \mathrm{~L} \mathrm{~d}^{-1}$, corresponding to average hydraulic retention times (HRT) of $1.25 \mathrm{~d}, 5 \mathrm{~d}$ and $10 \mathrm{~d}$ in the reactors. Each HRT treatment was performed in duplicate (6 reactors in total).

The reactors were constantly stirred by a motor-driven propeller-whisk, at approximate $32 \mathrm{rpm}$. An equal amount of the reactor volume to be renewed daily by fresh substrate addition was discharged from the reactors immediately prior to the loading of new substrate. Temperature, $\mathrm{pH}$ and oxygen were measured in the daily discharge from the reactors.

Laboratory samples for analysis (in triplicate) from the reactors and the 'raw sludge' (i.e. the pooled and stirred discharged solid fish waste and water) were taken twice during the study; 3 weeks after start-up and 11 days after this event. The 'raw sludge' was additionally sampled 5 times during the test period.

\subsection{Sample analysis}

Unfiltered samples were analyzed for total solids (TS) total volatile solids (TVS), suspended solids (SS) and volatile suspended solids (VSS) according to DS (Danish Standard) 204 and DS (Danish Standard) 207, and total COD (Hach Lange, LCK 914). Unfiltered raw sludge samples were additionally analyzed for total phosphorus (TP) by ISO 6878 and total Kjeldahl nitrogen (TKN) by ISO 5983-2. For analysis of dissolved compounds, the samples were filtered $(0.2 \mu \mathrm{m})$ after initial

centrifugation (4500 rpm, $5^{\circ} \mathrm{C}, 20 \mathrm{~min}$ ), and analyzed for content of volatile fatty acids (VFA) 
quantified as acetic acid by the Hach Lange spectrophotometric method (LCK 365), total ammonia nitrogen (TAN) by DS 224, ortho-phosphate (by omitting the digestion step in ISO 6878), and soluble COD by Hach Lange test kit (LCK 014).

\subsection{Statistical analysis of data and calculation of fermentation rates}

A two way repeated measures ANOVA in SigmaPlot 12.0 for Windows (Systat Software, Inc.) was used to test the differences between reactor types and retention (HRT) /hydrolysis times (HT) (regarding VFA yield and dissolution of N and P) and the Holm-Sidak method was used for the all pairwise multiple comparison procedure. Linear correlations between VFA and TAN or VFA and ortho-P generation were tested by linear modeling in R version 3 (2009-2012 RStudio Inc.).

Based on the measurements of the samples the VFA fermentation rate was estimated as: $\mathrm{VFA}_{\mathrm{r}}=\mathrm{VFA}_{\mathrm{T} 2}-\mathrm{VFA}_{\mathrm{T} 1} /\left(\mathrm{t}_{\mathrm{T} 2}-\mathrm{t}_{\mathrm{T} 1}\right)$ where; VFA: measured VFA yield, $\mathrm{t}$ : HRT or HT (d), T2: subsequent time point to $\mathrm{T} 1$.

\subsection{Assessment of the biochemical methane potential (BMP)}

The biochemical methane potential (BMP) of the sludge was measured by the assay proposed by Angelidaki et al. (2009). Three concentrations of sludge were evaluated; $8 \mathrm{~g} \mathrm{~L}^{-1} \mathrm{VS}$ (20\% sludge as substrate), $4 \mathrm{~g} \mathrm{~L}^{-1} \mathrm{TVS}(10 \%)$ and $2 \mathrm{~g} \mathrm{~L}^{-1} \mathrm{TVS}(5 \%)$, and digested cow manure was used as inoculum obtained from DTU Env-Bioenergy Laboratory. The rubber stopper closed bottles (540 $\mathrm{mL}$ ) were filled with $160 \mathrm{~g}$ inoculum and sludge substrate; i.e. $40 \mathrm{~g}(20 \%), 20 \mathrm{~g}(10 \%), 10 \mathrm{~g}(5$ $\%$ ), and a control with $0.5 \mathrm{~g}$ avicel (microcrystalline cellulose), and filled up with water to a total liquid volume of $200 \mathrm{~mL}$. The bottles were flushed with nitrogen gas to ensure anaerobic conditions and incubated at $35{ }^{\circ} \mathrm{C}$ for 24 days in triplicate per treatment. Methane content was measured by gas chromotography on day; $2,5,7,9,12,14,19$ and 21 .

The sludge used for this trial was retrieved from a different trout RAS system described in Suhr et al. (2014) but fed identical feed (Biomar Enviro 920) as in the anaerobic sludge digestion trials.

\section{Results}

\subsection{Sludge characteristics}

Approximately $507-513 \mathrm{~g}$ total solids (TS) with an average concentration of $11.65 \pm 1.15 \mathrm{~g} \mathrm{TS} \mathrm{L} \mathrm{L}^{-1}$ $(\mathrm{n}=18)$ was produced by the daily feeding of $3925 \mathrm{~g}$ feed to the fish. The unhydrolyzed raw solid 
waste had an average organic matter content of $7.57 \pm 0.87 \mathrm{~g} \mathrm{TVS} \mathrm{L}^{-1}(\mathrm{n}=18)$. When hydrolyzed for 10 days, the content of SS was reduced $43 \%$ (from $8.2 \pm 0.2$ to $4.7 \pm 0.2 \mathrm{~g} \mathrm{~L}^{-1}$ ) in $\mathrm{FB}$ and $28 \%$ in B (from $6.8 \pm 0.3$ to $4.9 \pm 0.5 \mathrm{~g} \mathrm{~L}^{-1}$ ). However, SS in the latter was reduced $37 \%$ when HT was increased to 20 days and by omitting a replicate (C) that differentiated from the others (as further shown below). No difference in total COD was detected during the experiment $(11.55 \pm 0.79$ (day 0) vs. $10.95 \pm 0.09$ (day 20)). At 10 days HT /HRT content of TVS decreased during hydrolysis (by $30 \%$ and $19 \%$ for FB and B, respectively).

\subsection{Volatile fatty acids (VFA) generation}

The VFA yield increased significantly with time but no effect of the method applied (B vs. FB) was found when hydrolyzing and fermenting the solid waste for up to 10 days HRT/HT. The highest VFA concentrations measured in the acidogenic digestion trials at HRT/HT day 10 were $203.4 \pm$ 11.2 and $222.3 \pm 30.5 \mathrm{mg} \mathrm{VFA} \mathrm{g}^{-1} \mathrm{TVS}_{0}$ in $\mathrm{FB}$ and $\mathrm{B}$, respectively. The corresponding maximum soluble COD (sCOD) / total COD (tCOD) ratio was $20 \%$ (FB) and $22 \%$ (B). No significant gain in VFA yield was found for FB reactors when increasing HRT from 5 to 10 days. Fermentation rates were fastest initially with VFA yields the first day of $79.9 \pm 15.0 \mathrm{mg}$ VFA $\left(\mathrm{g} \mathrm{TVS}_{0} \cdot \mathrm{d}_{(1.25)}\right)^{-1}$ in FB and $66.6 \pm 6.8 \mathrm{mg} \mathrm{VFA}\left(\mathrm{g} \mathrm{TVS}_{0} \cdot \mathrm{d}_{(1)}\right)^{-1}$ in B versus $15.6 \pm 0.5 \mathrm{mg} \operatorname{VFA}\left(\mathrm{g} \mathrm{TVS}_{0} \cdot \mathrm{d}_{(5)}\right)^{-1}(\mathrm{FB})$ and $14.7 \pm 2.3 \mathrm{mg}$ VFA $\left(\mathrm{g} \mathrm{TVS}_{0} \cdot \mathrm{d}_{(5)}\right)^{-1}(\mathrm{~B})$ at HRT/HT day 5 . There seemed to be a time effect for the FB mode as the VFA yields from the second sampling were higher than from the first ones (Fig.1) but this was not statistically (T-test) significant.

In the elongated B digestion two replicates produced more VFA beyond 10 days HT (reaching $273.9 \pm 1.6 \mathrm{mg} \mathrm{VFA} \mathrm{g}^{-1} \mathrm{TVS}_{0}$ at day 20) whereas one replicate (C) expressed VFA consumption. The deviating C-replicate at day 14 and 20 was also evident from the pH-values (Fig. 2). No inverse correlation between VFA content and $\mathrm{pH}$ was detected for FB contrary to B reactor experiment (Fig.1. and Fig.2).

\subsection{Remineralization of $N$ and $P$}

Soluble $\mathrm{N}$ and $\mathrm{P}$ compounds were released during the hydrolyzation of the organic matter. Initially (day 0 ) only $6-9 \%$ of the $\mathrm{N}$ and P were present as TAN and ortho-P. After 10 days HT or HRT, TAN made up $24 \%$ and $17 \%$ of the total Kjeldahl-N content, and ortho-P $53 \%$ and $44 \%$ of total $\mathrm{P}$, in the B and FB experiments, respectively (Table 1). The reactor type (B vs. FB) had no significant effect on $\mathrm{N}$ remineralization, only the time (HRT/HT) was significantly affecting TAN 
release. For P remineralization, besides time, the interaction between reactor and time was significant and this was caused by operational effects occurring at 5 days HRT/HT. No significant difference between HRT day 5 and 10 was found for P remineralization in FB, and between HT day 1 and 5 for $\mathrm{P}$ remineralization in B. One replicate (C) in the B experiment was clearly deviating from the others at day 10, 14 and 20 (Fig. 3), and day 10 was subsequently omitted from the data in Table 1.When correlating the VFA content to TAN and ortho-P content in the hydrolyzing batch experiment (Fig. 4), gross linear approximations could be made (correlation $r^{2}=0.93$ and $r^{2}=0.86$, respectively). If assuming such linear correlations, $31.2 \mathrm{mg}$ TAN and $77.4 \mathrm{mg} \mathrm{PO}$-P were produced per g VFA produced. Linear modeling in R, however, showed that only correlations below 5 days (for TAN) and 10 days (for ortho-P) were significant.

\subsection{The biochemical methane potential (BMP)}

The methane production measured in the BMP assay was $359 \pm 29 \mathrm{~mL} \mathrm{CH}_{4} \mathrm{~g}^{-1}$ TVS quantified as the average of all three concentrations tested and measured day 19, 21 and 24 (Fig. 5). This

corresponds to $318 \mathrm{~mL} \mathrm{CH}_{4} \mathrm{~g}^{-1} \mathrm{TVS}$ at standard temperature $\left(20^{\circ} \mathrm{C}\right)$ and pressure $(1 \mathrm{~atm}$.). Initially,

the specific methane generation was inversely correlated to substrate concentration, as the highest solid waste concentration showed the lowest specific methane yield (Fig. 5) but after one week of incubation (day 9 and onwards) this effect was blurred. The control showed an average maximum BMP of $414 \pm 7 \mathrm{~mL} \mathrm{CH}_{4} \mathrm{~g}^{-1}$ TVS (from day 19, 21 and 24) confirming the validity of the assay as the theoretical value for cellulose is $415 \mathrm{~mL} \mathrm{CH}_{4} \mathrm{~g}^{-1}$ TVS (DEM, 2003).

\section{Discussion}

\subsubsection{Biochemical acidogenic potential (BAP): Effect of reactor type (batch vs. fed-batch)}

BAP estimation is a valuable tool in biological nutrient removal engineering as the VFA content has a significant impact on the efficiency of the subsequent biological removal process (Lie and Welander, 1997). In this study, a significant increase in VFA yield was found at increasing HRT/HT and no significant difference was found between the two reactor types applied. The daily sludge loading of FB reactors was done in a waterfall manner $(60 \mathrm{~cm}$ from the inlet to the water 
level) which inevitably may have caused some oxygen infusion. E.g. Choubert et al. (2011) showed how a $30 \mathrm{~cm}$ waterfall in an automatic sampler affected VFA concentration and yield (compared to manual sample collection with low oxygen infusion) and lead to an underestimated BAP by up to $25 \%$. However, no clear effect of such oxygen infusion was found in this study when comparing FB and B VFA yield. This could indicate that the higher microbial growth rate and thereby higher enzymatic activity induced by the oxygen infusion compensated for the VFA loss due to aerobic respiration. The FB reactor showed a higher initial VFA generation rate compared to B and increasing HRT from 5 to 10 days did not increase the VFA yield. The latter was most likely caused by methanogenic activity at 10 days HRT. Clear indications of methanogenic activity in $\mathrm{B}$ reactor replicate $\mathrm{C}$ (VFA consumption and $\mathrm{pH}$ increase) $>10$ days HT was also observed. Based on the results from this study, recommendations for design of a continuously stirred pre-fermentor would suggest a HRT of 5 days in order to avoid methane production. This is comparable with wastewater conditions where $4-6$ days SRT for pre-fermentor operation is reported (Rössle and Pretorius, 2001). When optimum VFA generation rate rather than optimum final yield is determinant for prefermenter design, retention times of $30-40$ hours is found for return activated sludge in Danish wastewater treatment plants (Vollertsen et al. 2006).

In the present study FB reactors were operated for 32 days with two sampling sessions. The $2{ }^{\text {nd }}$ sampling session had the highest VFA yield and initial VFA generation rate (Fig.1). Further prolongation of the experimental period with more samplings would have been necessary to reject or confirm if microbial adaptation and/or other factors as presence of exoenzymes and lysed bacterial cells were factors affecting the VFA output. In support of an adaptation or time effect, VFA yield increased $48-170 \%$ in an acidogenic pre-fermentor by mixing partially fermented sludge with fresh sludge (Banister and Pretorius, 1998).

\subsubsection{Biochemical acidogenic potential (BAP): Remineralization of $P$}

A drawback to the use of solid fish waste for generating acidogenic C-compounds intended for denitrification is the simultaneous remineralization of $\mathrm{N}$ and $\mathrm{P}$. This was shown as the gross overall linear correlations between VFA - ortho-P and VFA - TAN observed in the BAP trials (Fig.4). From a pollution perspective this soluble $\mathrm{N}$ and $\mathrm{P}$ would have to be retained in the RAS before discharge.

Contrary to VFA yield and TAN release, P remineralization showed a significant difference between FB and B reactor types. A relatively steep increase (of a factor 2-3) in ortho-P content 
occurred at 5 days HRT for FB but at 10 days HT for B (Fig. 3) when discarding the continuous low values for one of the B replicates (C). Conroy and Couturier (2010) showed that solubilization of phosphorous (from $\mathrm{CaHPO}_{4} \cdot 2 \mathrm{H}_{2} \mathrm{O}$ ) in fish waste solids was a simple function of $\mathrm{pH}$ rather than the degradation of the solids per se. That is, ortho-P release is caused by the VFA production lowering the $\mathrm{pH}$ during the fermentation stage. In the present study, however, the high ortho-P content (FB > B) day 5 (Fig.3) is found at the highest $\mathrm{pH}(\mathrm{FB}>\mathrm{B})$ (Fig.2) contrary to the model predictions by Conroy and Couturier (2010). The reason for this discrepancy is unknown, but shows that other factors imposed by the differences in reactor type affected phosphorous solubilization during the anaerobic digestion. A possible explanation could be that the daily loading of FB reactors in a waterfall manner may have stripped off $\mathrm{CO}_{2}$ and thus induced a higher $\mathrm{pH}$. The lack of inverse correlation between VFA content and $\mathrm{pH}$ in FB compared to B reactors (Fig.1 and Fig.2) could support such an explanation but cannot be proved due to lack of continuously logged $\mathrm{pH}$-values in the FB reactors. Apart from simple chemistry, the presence of bacteria affecting P-transformations through poly-P storage and cleavage (Kerrn-Jespersen et al., 1994) cannot be totally disregarded although it seems highly unlikely that such a bacteria population had been established in the relatively short time span of the experiment. In summary, the highest VFA production initially (HT 1 day / HRT 1.25 d) coincided with the highest pH drop but ortho-P release was timely staggered from this. P-remineralization occurred in a relatively steep "stepwise" manner (at 5 days HRT in FB and 10 days HT in B) in the relatively narrow $\mathrm{pH}$ range $5.6-5.8$.

\subsection{Biochemical methane potential (BMP)}

The solid fish waste discharged from the RAS was subjected to a standardized BMP assay (Angelidaki et al., 2009) and showed a methane yield of $318 \pm 29 \mathrm{~mL} \mathrm{CH}_{4} \mathrm{~g}^{-1} \mathrm{TVS}$. This result is comparable to other values reported, e.g. $400 \mathrm{~mL} \mathrm{~g}^{-1} \mathrm{VS}$ from solid trout waste (Lanari and Franci, 1998) and $260-281 \mathrm{~mL} \mathrm{~g}^{-1}$ VS from solid salmon smolt waste (Gebauer and Eikebrokk, 2006). These values make solid fish waste from RASs equivalent to other manure types regarding energy efficiency for methane production, e.g. acidified pig manure $329 \mathrm{~mL} \mathrm{~g}^{-1} \mathrm{VS}$; cattle manure 198 $203 \mathrm{~mL} \mathrm{~g}^{-1} \mathrm{VS}$, chicken manure $290 \mathrm{~mL} \mathrm{~g}^{-1} \mathrm{VS}$ (Implement.nu, 2014). The drawback of solid fish waste compared to other manure types is the relative low solid content in the raw effluent stream and thus extra economical costs for solid fish waste up-concentrations. Assuming a production cost of $1.5 \mathrm{kWh} \mathrm{kg}^{-1}$ fish, which is representative for a Danish reuse system, and a conversion factor of $10 \mathrm{kWh} \mathrm{m}^{-3} \mathrm{CH}_{4}$, the energy recovered as methane in this study corresponded to $18 \%$ of the energy 
used. However, energy used for up-concentration of solids as well as methane reactor operation and maintenance was not included in this estimation. Gebauer and Eikebrokk (2006) estimated that about $2-4 \%$ of the energy demand of a flow-through hatchery was recovered by the methane yield of the sludge.

The initial methane values measured in the BMP assay showed increased methane yield at lower solid fish waste concentration. The lower concentration of solid waste had a higher active biomass to substrate concentration ratio initially, explaining the relationship measured (Fig.5). Equivalently, Conroy and Couturier (2010) also found that the fraction of solubilized P increased with decreasing solid concentration. After one week of incubation in the BMP assay the solid concentration effect was blurred (Fig.5) indicating that the active biomass: substrate relations were normalized with time in the different treatments.

\subsection{Maximizing the utility of the organic matter in RAS solid waste}

The 'raw' solid waste removed from the fish tanks contained approximately $1.4 \mathrm{~g} \mathrm{COD} \mathrm{g}^{-1} \mathrm{TVS}_{0}$. From this organic matter the yield of readily biodegradable carbon compounds measured as VFAs was $0.23 \mathrm{~g} \mathrm{VFA}-C O D ~ g^{-1} \mathrm{TVS}_{0}$ ( or $0.36 \mathrm{~g}$ total $\mathrm{sCOD} \mathrm{g}^{-1} \mathrm{TVS}_{0}$ ) in the batch BAP experiment. The yield of methane measured in the BMP assay corresponded to $0.91 \mathrm{~g} \mathrm{CH}_{4}-\mathrm{COD} \mathrm{g}^{-1} \mathrm{TVS}_{0}$, which made methanogenesis the most efficient process in terms of recovered energy. However, as the two end products $\left(\mathrm{VFA}, \mathrm{CH}_{4}\right)$ share the same initial anaerobic digestion steps (hydrolysis and fermentation), a considerable potential exists to further increase the VFA amount. It should be noted that the VFAs were quantified as acetic acid in the method (Hach Lange test kit) applied here, making the above VFA-COD value relatively lower than it would have been if each VFA species were identified. Nevertheless, as acetic acid constitutes the majority of the VFAs generated (Aboutboul et al., 1995) the approximation is appropriate and do not change the point conveyed above.

\section{Conclusions}

The biochemical acidogenic potential of the RAS solid waste showed a maximum VFA yield of 203 $-274 \mathrm{mg} \mathrm{g}^{-1} \mathrm{TVS}_{0}$ or a dissolution of $20-22 \%$ (soluble COD of) total COD. No effect of the reactor type used (batch vs. fed-batch) on VFA yield was found within the time frame of the experiments. This supported the use of batch methodology as a tangible tool for RAS sludge examinations. The acidogenic anaerobic digestion solubilized $16.8-23.5 \%$ of total Kjeldahl $\mathrm{N}$ as 
TAN and $44.3-53.0 \%$ of total P as ortho-phosphate. In a RAS effluent perspective these soluble nutrients will have to be transformed or precipitated prior to discharge. The measured biochemical methane potential of $318 \pm 29 \mathrm{~mL} \mathrm{CH}_{4} \mathrm{~g}^{-1} \mathrm{TVS}_{0}(\mathrm{STP})$ represented a higher utility of the solid waste when performing complete anaerobic digestion (about $65 \%$ of total COD) than the acidogenic product of the partial digestion process (about $26 \%$ of total COD), and thereby indicating the potential room for further improving the acidogenic potential.

\section{Acknowledgements}

The invaluable technical support of Ulla Sproegel, Brian Møller, Dorthe Frandsen, Ole Madvig Larsen, Rasmus Frydenlund Jensen, and Erik Poulsen is highly appreciated. This work was conducted as part of AQUABEST a Baltic Sea regional programme 2007-2013 part-financed by the European Union (European Regional Development Fund and European Neighbourhood and Partnership Instrument).

\section{References}

Aboutboul, Y., Arviv, R., van Rijn, J., 1995. Anaerobic treatment of intensive fish culture effluents: volatile fatty acid mediated denitrification. Aquaculture 133, $21-32$.

Angelidaki, I. Alves, M. Bolzonella, D. Borzacconi, L. Campos, J.L. Guwy, A.J. Kalyuzhnyi, S. Jenicek, P. and van Lier, J. B., 2009. Defining the biomethane potential (BMP) of solid organic wastes and energy crops: A proposed protocol for batch assays. Water Sci. Technol. 59 (5), 927 934.

Appels, L. Baeyens, J., Degrève, Dewil, R., 2008. Principles and potential of the anaerobic digestion of waste-activated sludge. Prog. Energ. Combust. 34, 755 - 781.

Banister, S.S., Pretorius, W.A., 1998. Optimisation of primary sludge acidogenic fermentation for biological nutrient removal. Water SA 24 (1), $35-41$.

Barnard, J.L., 1974. Cut P and N without chemicals. Water Waste Eng. 11(7), 33-36.

Choubert, J.-M., Granger, D., Bourdon, C., Héduit, A., 2011. Biochemical acidogenic potential in domestic wastewaters: Effect of sampling and storage to characterize daily average composite samples. Water Sci. Technol. 63(7), 1396-1404. 
Conroy, J., Couturier, M., 2010. Dissolution of minerals during hydrolysis of fish waste solids. Aquaculture 298, 220-225.

Cripps, S.J., Bergheim, A., 2000. Solids management and removal for intensive land-based aquaculture production systems. Aquacult. Eng. 22, 33-56

Danish Environmental Ministry (DEM), 2003. Basis for the biogaspotential of organic matter in garbage collection. Report documentation. Christensen, T.H., Hansen, T.L., Kirkerby, J.T., Jansen, L la C., Svärd, Aa., Toudal, J.K., Hulgaard, T., Rasmussen, H.W., Gruvberger, C. 8 Jan 2014. < http://www2.mst.dk/common/Udgivramme/Frame.asp?http://www2.mst.dk/udgiv/publikationer/200 3/87-7972-590-2/html/bilag03/kap02.htm>

DS (Danish Standard) 204, 1980. Determination of total residue and total fixed residue in water, sludge and sediment. Danish Standard, DS 204:1980, 4 pp.

DS (Danish Standard) 207, 1985. Total non filtrable residue and fixed matter in non filtrable residue. Danish Standard, DS 207:1985, 4 pp.

DS (Danish Standard) DS 224. Water analysis - determination of ammonia nitrogen. DS 224:1975, 8pp.

Eastman, J.A., Ferguson, J.F., 1981. Solubilization of particulate organic carbon during the acid phase of anaerobic digestion. J. WPCF 53 (3), 352 - 366.

Gebauer, R., Eikebrokk, B., 2006. Mesophilic anaerobic treatment of sludge from salmon smolt hatching. Bioresource Technol. 97, $2389-2401$.

Goel, R., Mino, T., Satoh, H., Matsuo, T., 1997. Effect of electron acceptor conditions on hydrolytic enzyme synthesis in bacterial cultures. Water Res. 31 (10), $2597-2603$.

Goel, R., Mino, T., Satoh, H., Matsuo, T., 1998. Comparison of hydrolytic enzyme systems in pure culture and activiated sludge under different electron acceptor conditions. Water Sci. Technol. 37 (4-5), $335-343$.

Henze, M. Mladenovski, C., 1991. Hydrolysis of particulate substrate by activated sludge under aerobic, anoxic and anaerobic conditions. Water Res. 25, 61 - 64. 
Implement.nu, 2014. EU Interreg project on biogas. Spreadsheet containing the biogas potential of different manure types. 8 Jan 2014. < http://implement.nu/wpcontent/uploads/2013/06/Biogasdatagrundlaget_regneark.pdf $>$ ISO (International Organization for Standardization) 6878, 2004. Water quality — determination of phosphorus - ammonium molybdate spectrometric method, ISO 6878:2004. International Organization for Standardization, Geneva. 21 pp.

ISO (International Organization for Standardization) 5983-2, 2005. Animal feeding stuffs determination of nitrogen content and calculation of crude protein content - part 2: block digestion/steam distillation method, ISO 5983-2:2005. International Organization for Standardization, Geneva. 14 pp.

Kerrn-Jespersen, J.P., Henze, M., Strube, R., 1994. Biological phosphorus release and uptake under alternating anaerobic and anoxic conditions in a fixed-film reactor. Water Res. 28 (5), 1253 - 1255. Lanari, D., Franci, C., 1998. Biogas production from solid wastes removed from fish farm effluents. Aquat. Living Resour. 11 (4), $289-295$.

Lie, E. and Welander, T., 1997. A method for determination of the readily fermentable organic fraction in municipal wastewater. Water Res. 31, 1269-1274.

Metcalf and Eddy, 2003. Wastewater engineering: Treatment and reuse. $4^{\text {th }}$ ed. New York: McGraw-Hill. 1819 pp.

Mirzoyan, N., Tal, Y., Gross, A., 2010. Anaerobic digestion of sludge from intensive recirculating aquaculture systems: Review. Aquaculture 306, 1 - 6.

Mirzoyan, N., McDonald, R.C., Gross, A., 2012. Anaerobic Treatment of Brackishwater Aquaculture Sludge: An alternative to Waste Stabilization Ponds. J World Aquacult. Soc. 43, 238 248.

Pitman, A.R., Lötter, L.H., Alexander, W.V., Deacon, S.L., 1992. Fermentation of raw sludge and elutriation of resultant fatty acids to promote excess biological phosphorus removal. Water Sci. Technol. 25 (4-5), $185-194$. 
Ruel, S.M, Comeau, Y., Héduit, A., Deronzier, G., Ginestet, P., Audic, J.M., 2002. Operating conditions for the determination of the biochemical acidogenic potential of wastewater. Water Res. $36,2337-2341$.

Rössle, W.H., Pretorius, W.A., 2001. A review of characterization requirements for in-line prefermenters Paper 2: Process characterization. Water SA 27 (3), 413 - 421.

Sharrer, M., Rishel, K., Taylor, A., Vinci, B.J., Summerfelt, S.T., 2010. The cost and effectiveness of solids thickening technologies for treating backwash and recovering nutrients from intensive aquaculture systems. Bioresource Technol. 101, 6630-6641.

Shnel, N., Barak, Y., Ezer, T., Dafni, Z., van Rijn, J., 2002. Design and performance of a zerodischarge tilapia recirculation system. Aquacult. Eng. 26, 191-203.

Suhr, K.I., Arvin, E., Pedersen, P.B., 2013. End-of-pipe denitrification using RAS effluent waste streams: Effect of C/N-ratio and hydraulic retention time. Aquacult. Eng. 53, 57-64.

Suhr, K.I., Pedersen, L.-F., Nielsen, J.L., 2014. End-of-pipe single-sludge denitrification in pilotscale recirculating aquaculture systems. Aquacult. Eng. 62, 28 - 35 .

Tal, Y., Schreier, H.J., Sowers, K.R., Stubblefield, J.D., Place, A.R., Zohar, Y., 2009. Environmentally sustainable land-based marine aquaculture. Aquaculture 286, 28-35.

van Lier, J.B., Tilche, A., Ahring, B.K., Macarie, H., Moletta, R., Dohanyos, M., Hulshoff Pol, L.W., Lens, P., Verstraete, W., 2001. New perspectives in anaerobic digestion. Water Sci. Technol. $43(1), 1-18$.

van Rijn, J., Fonarev, N, Berkowitz, B., 1995. Anaerobic treatment of intensive fish culture effluents: digestion of fish feed and release of volatile fatty acids. Aquaculture 133, 9 - 20.

van Rijn, J., Tal, Y., Schreier, H.J., 2006. Denitrification in recirculating systems: Theory and applications. Aquacult. Eng. 34, 364-376.

Vollertsen, J., Petersen, G., Borregaard, V.R., 2006. Hydrolysis and fermentation of activated sludge to enhance biological phosphorus removal. Water Sci. Technol. 53 (12), 55 - 64. 
Table 1. Dissolution of N (as TAN) and P (as ortho-P) in batch and fed-batch reactors expressed as the percentage of the total amounts available.

HT: hydrolysis time in batch reactors; HRT: hydraulic retention time in fed-batch reactors.

\begin{tabular}{crrrrr} 
& \multicolumn{2}{c}{$\%$ TAN of total $\mathrm{N}^{\mathrm{a}}$} & & \multicolumn{2}{c}{$\%$ ortho-P of total P } \\
\cline { 2 - 3 } \cline { 5 - 6 } HT / HRT $(\mathrm{d})$ & \multicolumn{1}{c}{ Batch } & Fed-batch & & \multicolumn{1}{c}{ Batch } & \multicolumn{1}{c}{ Fed-batch } \\
\hline 0 & $8.3 \pm 0.6$ & $7.1 \pm 1.6$ & & $8.7 \pm 0.3$ & $5.8 \pm 0.3$ \\
$1 / 1.25^{\mathrm{b}}$ & $10.8 \pm 1.1$ & $7.2 \pm 1.0$ & & $17.4 \pm 1.4$ & $16.0 \pm 2.8$ \\
5 & $17.4 \pm 2.5$ & $13.8 \pm 2.9$ & & $23.0 \pm 3.0$ & $44.0 \pm 2.2$ \\
10 & $23.5^{\mathrm{c}} \pm 3.2$ & $16.8 \pm 3.3$ & & $53.0^{\mathrm{c}} \pm 4.8$ & $44.3 \pm 0.9$ \\
\hline
\end{tabular}

${ }^{\mathrm{a}} \mathrm{N}$ measured as Kjeldahl-N.

${ }^{\mathrm{b}}$ Fed-batch reactors HRT $1.25 \mathrm{~d}$.

${ }^{\mathrm{c}}$ Average of replicates B_a and B_c only. 

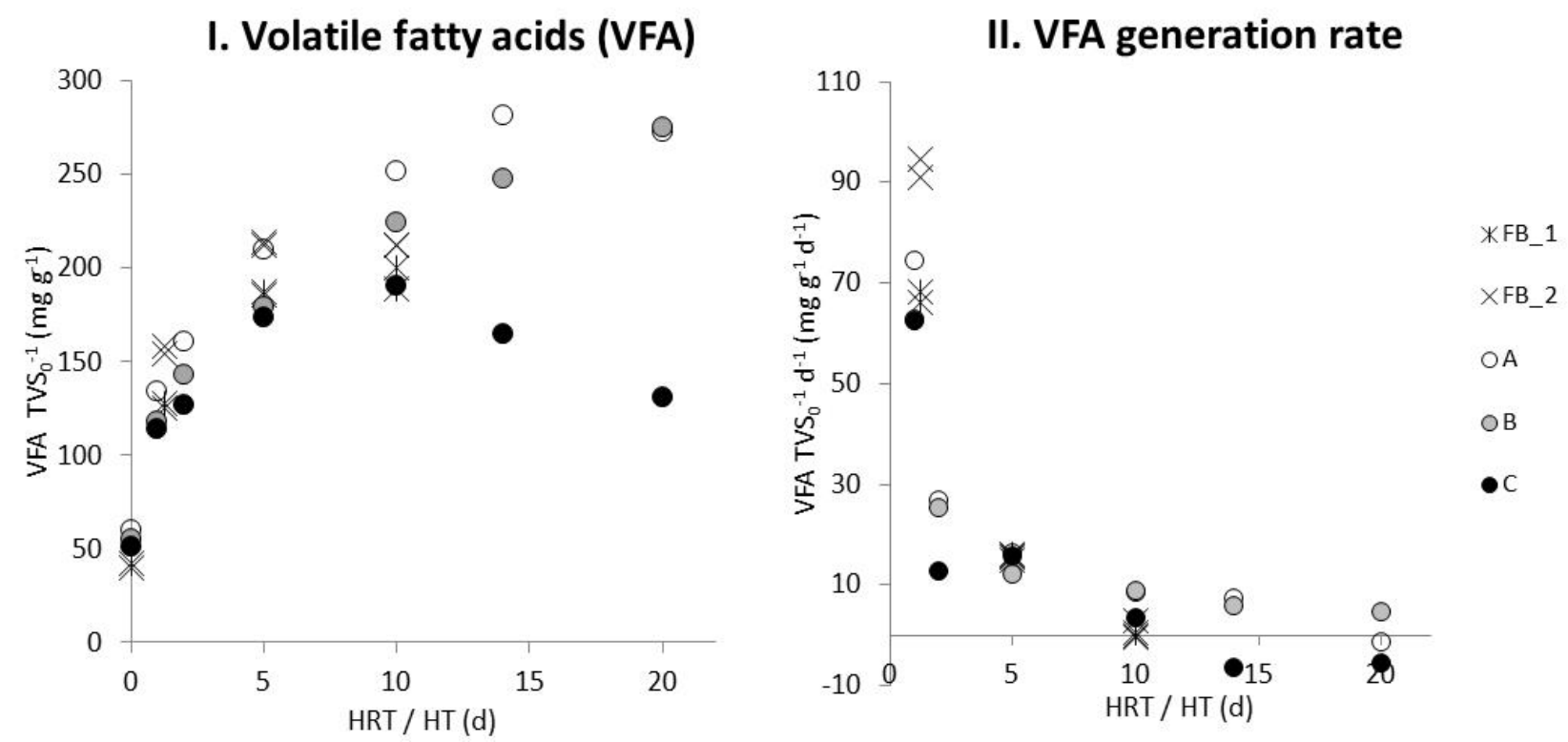

Fig. 1. I) Volatile fatty acid (VFA) content in fed-batch (FB) reactor (duplicate reactors at each replicate run _1, _2) and batch (B) reactor (triplicate B_a, B_b, B_c). II) The VFA generation rate estimated as: VFA $\bar{T}_{2}-V_{F 1} /\left(t_{T 2}-t_{T 1}\right)$ where VFA: measured VFA yield, $t$ : hydraulic retention time (HRT) / hydrolysis time (HT) (d), T2: subsequent time point to T1. 


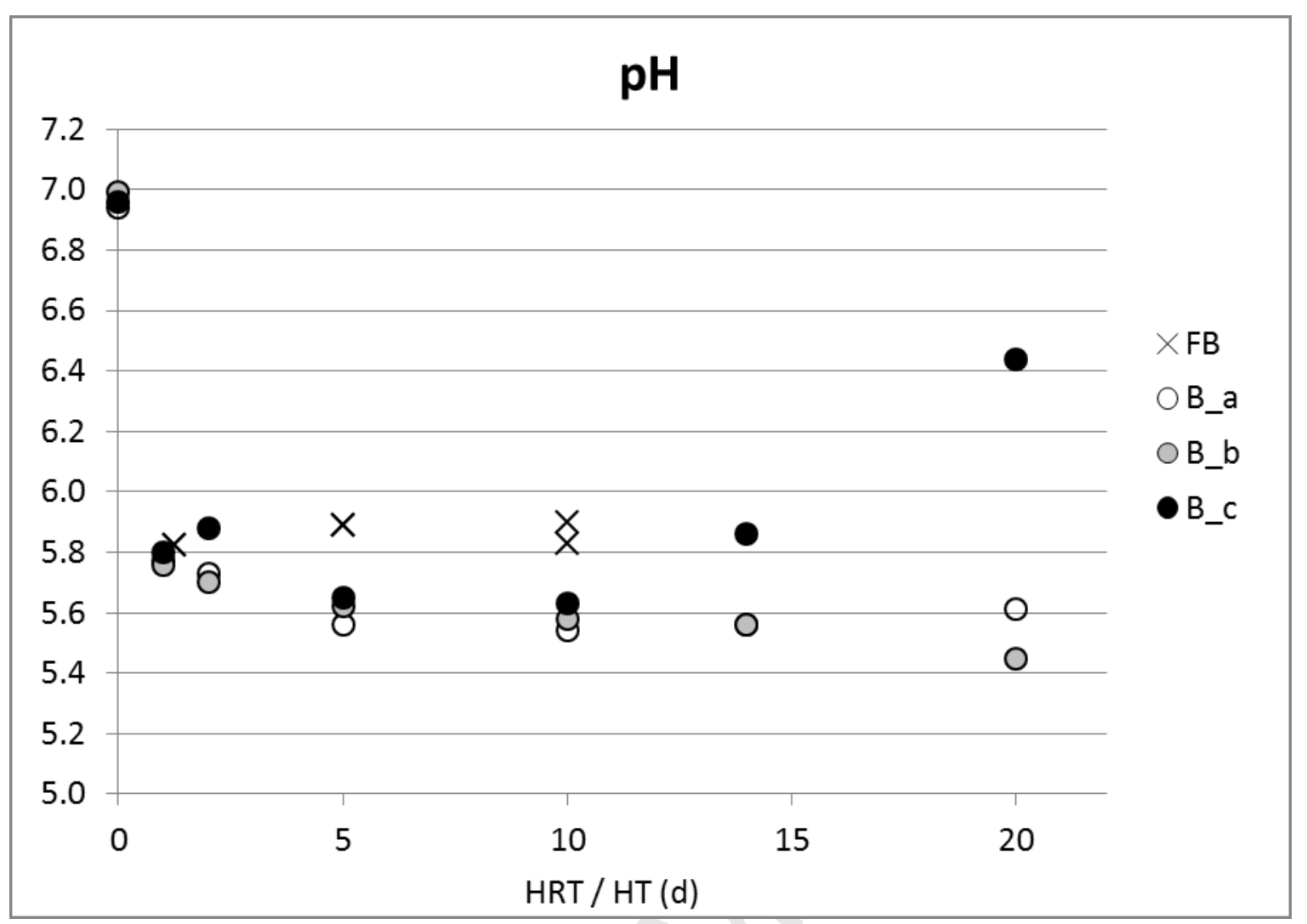

Fig. 2. The $\mathrm{pH}$ values measured in fed-batch $(\mathrm{FB})$ reactors (duplicate tanks, $n=20$ daily measurements per tank) and in batch (B) reactors (triplicate B_a, B_b, B_c). Hydraulic retention time (HRT) and hydrolysis time (HT). 


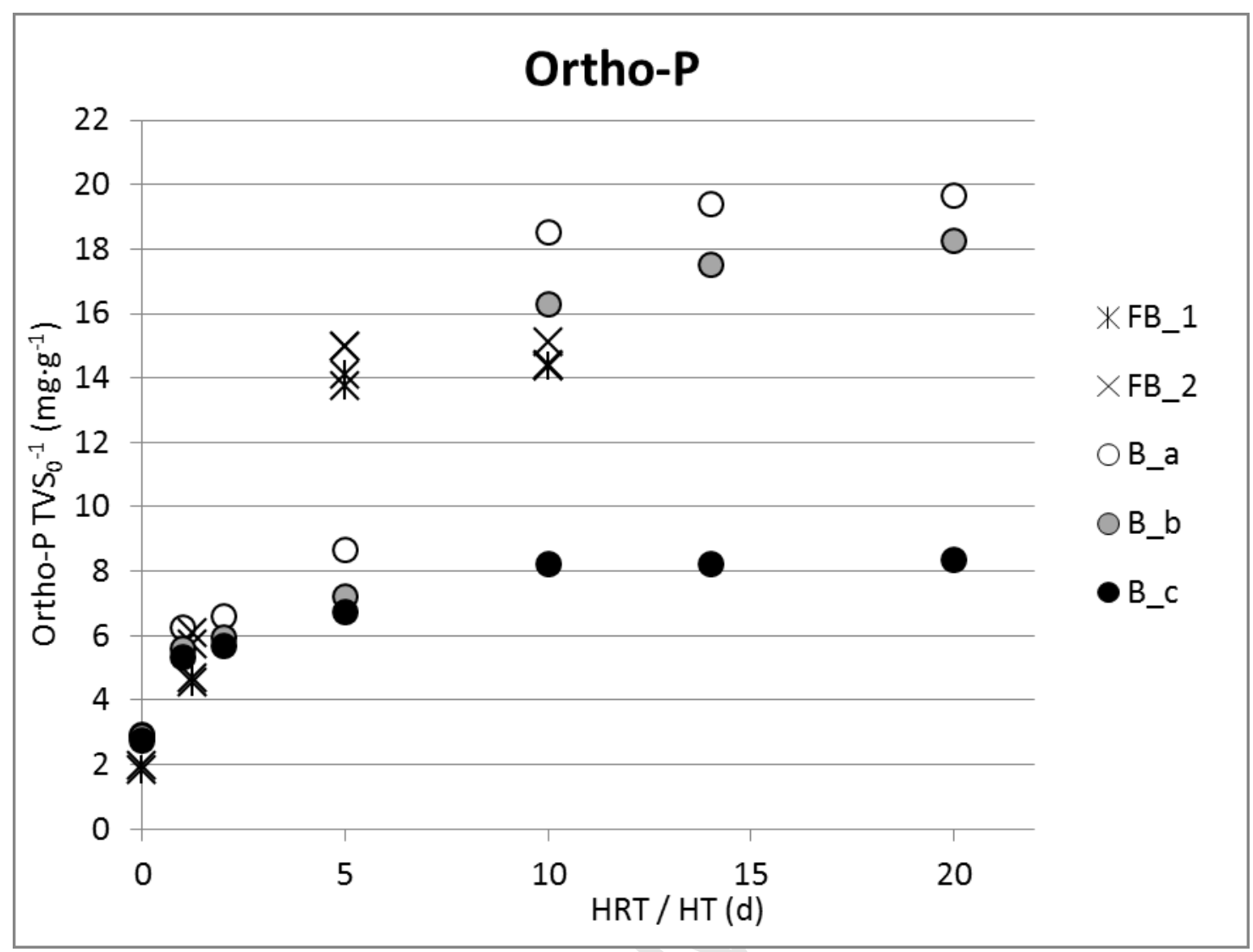

Fig. 3. Ortho-P content in fed-batch (FB) reactor (duplicate reactors at each replicate run _1, 2) and batch (B) reactor (triplicate B_a, B_b, B_c). Hydraulic retention time (HRT), hydrolysis time (HT). 
(A) TAN vs. VFA

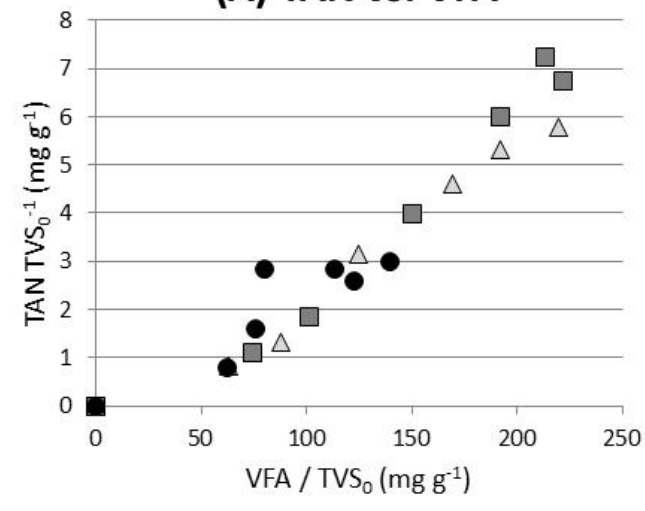

(B) ortho-P vs. VFA

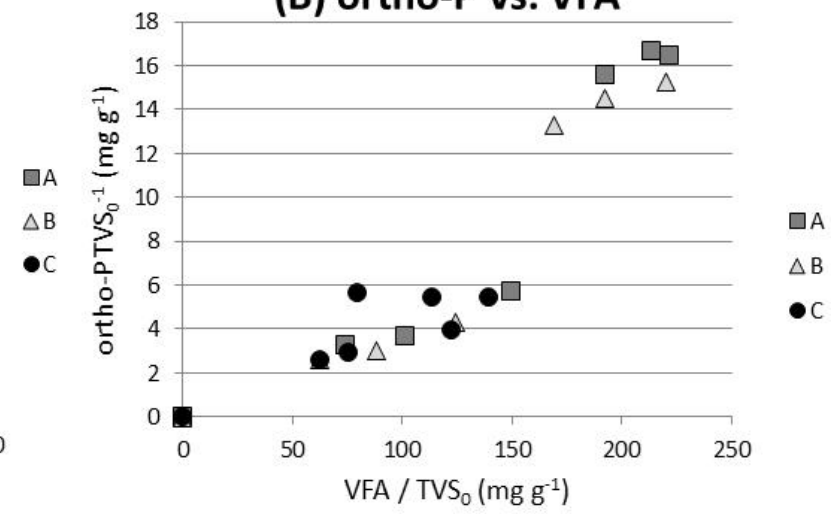

Fig. 4. The linear correlations of (A) TAN versus VFA and (B) Ortho-P versus VFA yield in the batch experiment (triplicate reactors $\left.B \_a, B \_b, B \_c\right)$. The linear correlations were $(A) y=0.0312 x-0.637, r^{2}=0.93$ and $(B) y=0.0774 x-2.140, r^{2}=0.86$ 


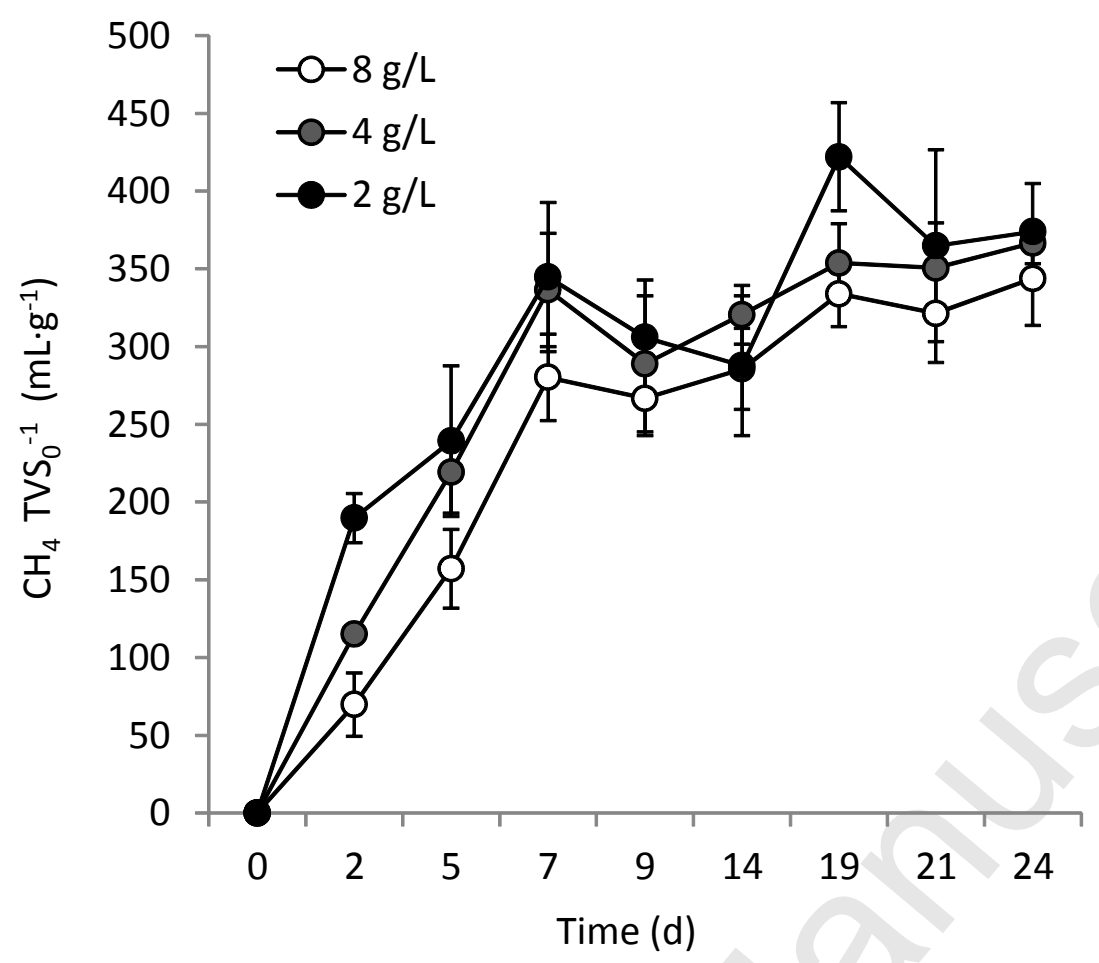

Fig. 5. Production of methane during the 24 day incubation at $35^{\circ} \mathrm{C}$ using cow manure as inoculum for solid fish waste in three concentrations $\left(2 \mathrm{~g} \mathrm{~L}^{-1}, 4 \mathrm{~g} \mathrm{~L}^{-1}, 8 \mathrm{~g} \mathrm{~L}^{-1}\right)$ each concentration tested in triplicate. 


\section{Highlights}

- Biochemical acidogenic potential of solid fish waste: $203-274 \mathrm{mg} \mathrm{VFA} \cdot \mathrm{g}^{-1} \mathrm{TVS}_{0}$

- No effect of the methodology (batch vs. fed-batch) on VFA yield

- Remineralization: $16.8-23.5 \%$ of TKN as TAN and $44.3-53.0 \%$ of TP as ortho-P

- Differences in P-solubilization at day 5 in batch vs. fed-batch reactor

- Biochemical methane potential of solid fish waste: $318 \pm 29 \mathrm{~g} \mathrm{CH}_{4} \cdot \mathrm{g}^{-1} \mathrm{TVS}_{0}$ 